\title{
LEGAL FRAMEWORK FOR HIGHER EDUCATION QUALITY STATE STANDARDS. A CASE OF ALBANIA
}

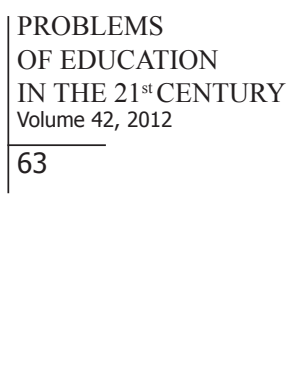

Juliana Latifi

Justicia University, Tirana, Albania

E-mail: julilatifi@yahoo.com

\begin{abstract}
Albania's higher education development is very dynamic. Higher education in Albania is being characterised by a massive expansion process and by competition between both the public and private education sectors. The number of higher education institutions has grown fivefold during the last eight years. There are currently thirteen (13) public and forty six (46) private institutions.

This article is aimed at the research of analysing the legal framework for higher education quality state standards.

This analysis will address three important issues:

1. What is the legal framework for higher education quality state standards?

2. How is the quality assured in higher education institutions?

3. To what extent are Albanian quality standards compared to the European ones?

This study is based on an analysis of the domestic and European legislation, interviews with fifteen (15) key persons that are divided in three groups: officials of the Ministry of Education and Science/Public Agency for the Accreditation of Higher Education, officials of public Higher Education Institution, and officials of private Higher Education in Albania including reports and policy documents.

The conclusions of this research article will help in understanding the role of the higher education quality state standards and will contribute to the improvement of the quality legal framework in the country.
\end{abstract}

Key words: standard, quality, legal framework, quality standards, higher education.

\section{Introduction}

In the last decade, higher education in Albania is facing both quantitative and qualitative changes. At present, the higher education landscape is very dynamic. The number of higher education institutions (HEI), especially private institutions, has noticeably increased. There are forty six (46) private and thirteen (13) public institutions. The increase in number of private HEI has clearly affected the higher education quality.

The quality assurance both in public and private HEI, within a framework with clearly defined standards, represents a challenge in the context of European processes that the Albanian education is going towards as required by the participation in the Bologna process in 2003. This includes the signing of the Stabilisation and Association Agreement done between Albania and the EU Member States in June 2006 (Art.100, Law No. 9590, dated 27 July 2006, On the Ratification of 'Stabilization and Association Agreement between the Republic of Albania and the European Communities and their Member States', June 2006).

Facing a reality which increasingly requires a higher education system closer to the European Higher Education Area standards, the Albanian Government, pursuant to Law No. 9741, dated 21 May 2007 'On Higher Education in the Republic of Albania', as amended (Art. 
PROBLEMS

OF EDUCATION

IN THE $21^{\text {st }}$ CENTURY Volume 42, 2012

61), has adopted the higher education quality state standards which have been considered as the

'Legal framework for quality state standards' and which comprises of:

1. Minister of Education and Science Order No. 126, dated 17 March 2011, "On the adoption of quality state standards for the assessment and institutional accreditation of higher education institutions".

2. Minister of Education and Science Order No. 134, dated 21 March 2011 "On the adoption of quality state standards for the assessment and accreditation of higher education institutions' first cycle study programs".

3. Minister of Education and Science Order No. 135, dated 21 February 2011 "On the adoption of quality state standards for the assessment and accreditation of higher education institutions' second cycle study programs".

4. Minister of Education and Science Order No. 136, dated 21 February 2011 "On the adoption of quality state standards for the assessment and accreditation of higher education institutions' third cycle study programs".

Pursuant to the Law on Higher Education, the abovementioned subordinate legal acts and a series of other legal documents, this article is aimed at analysing the legal framework of higher education quality state standards from two perspectives: institutional standards of HEI and standards of study programs in the three study cycles, Bachelor, Master, and $\mathrm{PhD}$.

The analysis of the legal documents will introduce the novelties resulting from the standards, as well as the problems they bear, which result from the low quality and credibility of HEI in Albania provided at present.

Through a critical analysis, the article will also address quality control mechanisms within and outside of the institution; what is the situation of these mechanisms and what is to be done to assure that quality state standards are observed and applied.

The interviews with key selected persons are divided in three groups: officials of the Ministry of Education and Science/Public Agency for the Accreditation of Higher Education (PAAHE), officials of public HEI, and officials of private HE. These will suggest their opinions in order to evaluate the possible rate of application and observation of these standards by HEI and their officials.

Finally, the quality state standards will be addressed to observe to what extent they are similar to the standards used in the European Higher Education Area. What should be done in order for the Albanian standards to be close to those of the European Higher Education Area to be equivalent and competitive with?

\section{Research Methodology}

In order to provide an understanding of how this research was conducted and how the information was obtained, the following will show the research methods used and the criteria for selecting participants for this study.

The research methodology was based on quality research methods: documentation analyses and interviewing.

A documentation analysis involves reviewing all readily available materials. These materials include laws and by laws, policy documents, reports and publications on the researched topic. The method for analysing the information was based on content analysis.

Personal interviews with 15 key persons were used as a way to get in-depth and comprehensive information. The purpose of the interviews was to gather information that is not publicly available and to generate insights on the issue of the quality assurance. The interview was semi structured and questions were prepared in advance.

The interviewed people were divided in three groups: a) three officials from the Ministry of Education and Science, b) two officials from the Public Agency for the Accreditation of 
Higher Education, c) six officials from the public HEI and four officials from the private HE in Albania. Knowing about their experiences was a very valuable way to understand their opinions in relation to the quality assurance.

The interviews were recorded because of the open ended questions. This meant that most answers were extensive and therefore writing them down would both take too much time and reduce people's time. The recordings also allowed having people's explanations and opinions obtained on a shorter period of time. In some cases people provided more information than expected, which was very helpful for the research.

The type of questions was selected were according to the research objectives. The interviews were held face to face.

For the purposes of this research were used primary sources, i.e., original documents as laws and by laws, policy documents; data from the interviews and secondary sources as internal and external reports presented for the purposes of the accreditation, analyses on the activity of the PAAHE, and published papers on the quality assurance in higher education.

Since the interviews were based on open ended questions, the results were transcribed and codified in order to develop the data analysis. Answers were codified according to the most common responses provided by interviewees therefore, the information was classified into answer categories.

The methodology used in this study was based on the research questions, the problems to be addressed and also based on the theoretical basis.

\section{Legal Framework of Quality Standards in the Area of Higher Education}

"The legal framework of quality state standards" is focused in two main directions:

- Standards to be met by a higher education institution in order to be evaluated and accredited, called "institutional standards".

- Standards to be met by study programs in the three study cycles in order to be evaluated and accredited, called "standards of study programs".

The Minister of Education and Science Order No. 126, dated 17 March 2011 "On the adoption of quality standards for the assessment and institutional accreditation of higher education institutions", states: "Quality State Standards represent the bulk of requirements and criteria an institution shall meet and they serve as a series of recommendations which assist higher education institutions achieve a certain development rate".

Each standard in itself consists of a list of criteria/requirements which the order cited above defines as: "Examples of best practices arranged in a non-final form (author's note: thus, which have not been assessed thoroughly). They shall assist the institution in fulfilling standards in favour of quality improvement".

Based on the definition given to the "standards", it might be said that they are not of a binding nature and their application is subject to the institution's discretion. The same thing also applies for their criteria which serve as an example on showing how the standards may be met.

\section{Institutional Standards}

Institutional standards are focused on three main directions:

- $\quad$ study programs;

- $\quad$ scientific activity;

- management of the institution.

Making reference to these three directions included in the Minister of Education and 
PROBLEMS

OF EDUCATION

IN THE $21^{\text {st }}$ CENTURY

Volume 42, 2012

Science Order No. 26, it can be clearly observed that the legal framework which regulates the institutional standards mixes up the institutional requirements with the requirements to be met by the study programs.

Seen from this perspective, the standards regarding study programs are addressed in parallel orders. In actual terms there is a general order, Order No. 126, and then there are special orders for each study cycle, Orders No. 134, No. 135, and No. 136 respectively. In this way, the standards' scheme becomes vague and overloaded.

On the foundation of Order No. 126, making reference to the three main directions of institutional standards and addressing them one by one, we will observe their structuring, the problems they display, and also the novelties they produce in some cases.

The list of standards addressed to the study programs in this order is very long and it includes a variety of criteria/requirements in itself.

Thus, the standards of the study programs include the following:

1. The institution shall provide study programs in compliance to its mission and capacities.

2. The continuous education shall be an integral part of study programs.

3. Study programs shall be provided in compliance with the institution's development strategy.

4. The study programs shall be provided in compliance with local, national, and international trends.

5. Study programs shall be provided in compliance with the institution's capacities.

6. Study programs shall be easily understandable and their objectives shall be clearly defined.

7. First cycle study programs shall equip students with basic knowledge on general scientific methods and principles.

8. First cycle study programs shall be drafted in such way to facilitate the adaptation of the student with the university environment.

9. Second cycle study programs shall be based on research, and for the purpose of their fulfilment, the institution shall cooperate with stakeholders in the economic area.

10. Study programs shall be aimed at achieving the mobility of Albanian students in Europe and beyond.

11. Study programs shall enable the practical application of knowledge and abilities gained by students in theoretical courses.

12. The announced study program shall be applied in adequate conditions.

13. Higher education institutions shall equip students, who meet all the requirements of a study program, with the relevant diploma which is an official document.

14. Study programs shall be subject to continuous improvement for the purpose of quality improvement.

15. The institution shall follow a clear policy regarding the education quality improvement.

None of these standards are accompanied by guidelines on how to be applied. There is just the arrangement of criteria each of them is comprised from and the institution selects among them. There is no distinction on which of them are mandatory and which are not. Their applicability is subject to the discretion of the institution to which they are recommended.

However, taking into account the higher education situation, where the content of the majority of study programs does not meet the future needs of the society and economy, HEI have done no more than repacking the existing programs and they have not moved towards the "learning results" approach (Higher Education National Strategy, 2008-2013). It is very clear that without being given mandatory attributes, these standards, especially the ones considered as most important, will exist only de jure having no acting power. 
The second focus of institutional standards is scientific research. The standards comprising it include the following:

1. The department, as a basic unit of the institution, shall identify its strengths and weaknesses in the area of scientific research.

2. The institution shall encourage development, dynamism and scientific research.

3. The institution shall focus on the internationalisation of scientific research.

4. The institution shall specify the primary areas of scientific research.

5. The institution shall apply the scientific research priorities.

6. The institution shall provide continuation in the area of scientific research.

7. The institution shall inform over the results in the area of scientific research.

8. The institution shall follow a policy for the evaluation and transfer of results in the area of scientific research.

The way on how the legal document in this regard has been drafted, creates the impression that scientific research must be a standard of each HEI, regardless of their mission. However, Albania faces a reality in which private HEI are only of an educational nature and the same thing applies for the majority of public HEI located outside Tirana (capital of Albania).

Based on different missions of HEI, we may say that scientific research will be carried out only in those HEI which have established a scientific research tradition, have an adequate and experienced academic potential to which institutes or scientific research centres are integrated.

On the other hand, the questioning of the interviewees in this respect identified the need for: scientific research, which is accompanied by high costs to impose the selective focusing in some priority areas or directions, because only in this way its impact can be enhanced at the largest extent.

Moreover, the university models in Western Europe, combining teaching with scientific research, are considered as the "golden standard", because they are able to exert control over the economies of their countries as well as to affect the economies with their scientific research. Similarly, a number of countries of Eastern Europe have demonstrated the expansion of specialised universities that have focused, for example, on economic or healthcare studies (Linden, Arnhold, \& Vasiliev, 2008).

Albanian universities, especially public ones (University of Tirana, Polytechnic University, Agricultural University), which have considerable human and material capacities, may achieve a combination of the education and scientific research missions with the latter being able to have its own impact in the development of the country.

The most important issue of Order No. 26, which should have determined institutional standards, is the "management of the institution". The concept of institutional management is a legal obligation, expressively envisaged in the provisions of the law on higher education (Art. 16) and accompanied also by the establishment of a special mechanism with HEI (especially public ones where it operates), the Council of Administration. It is a decision-making collegial body which supervises and controls the activities of the higher education institution related to its administrative management, financial management and economic management.

In accordance with the legal document, the management of the institution is focused on some main standards:

1. Autonomy;

2. Organisation of higher education institutions;

3. Partnership;

4. Management of human resources;

5. Management of the institution's activity;

6. Financial management;

7. Management of information systems.

Regarding these standards, we may say they represent a change and they are aimed at producing the modern concept of management for HEI in Albania.

From an institutional point of view, I believe that these standards must be made 
PROBLEMS

OF EDUCATION

IN THE $21^{\text {st }}$ CENTURY

Volume 42, 2012

"mandatory". They should be imposed on HEI in order for them to gain real and functional autonomy which implies not only to the academic autonomy, but also structural, administrative, and financial autonomy.

The interviewees believe that the requirements regarding management standards will have a positive impact because they are aimed at increasing the awareness of HEI on their existence as institutions with a certain legal status, which know how to self-manage human and financial resources and establish adequate structures to the benefit of their purpose and mission.

All these standards, recommended by Minister of Education, Order No. 126, rightfully lead to the questions:

- What is the awareness extent of HEI on the importance to observe such standards?

- What is the binding power of these standards and which sanctions will HEI and their directors face if they fail to observe them?

- Is the awareness of public HEI higher compared to private ones when it comes to meeting these standards, given that they are funded by the state budget and they comprise approximately the bulk of $90 \%$ of the students'?

- Is the awareness of private HEI higher when it comes to meeting these standards, so as to gain certain autonomy and to be competitive in the education market?

In my opinion including the opinions of the key persons I interviewed, in the current situation of the higher education in Albania which is characterized by a low credibility rate, is accused of formalism, fictiveness, influenced by politics and in some cases it is accompanied by phenomena of a corruptive nature. It is therefore necessary for institutional standards to be binding, especially those related to institutional management.

The awareness of both public and private HEI in this regard, is low. One of the indicators for this is the fact that the major public university, that is, the University of Tirana, has not accepted to undergo the evaluation and institutional accreditation process (PAAHE, Annual Report, 2011).

On the other hand, private HEI are characterized by a very high rate of fictiveness; only twelve (12) private HEI are institutionally accredited (PAAHE, Annual Report, 2011).

Lacking of adequate programs which meet the needs and requirements of the labour market and the current European development trend, lacking of duly academic staff and appropriate infrastructure, private HEI continue to flourish in the framework of the "education liberalization", which has no criterion.

\section{Standards of Study Programs}

The standards of study programs of the three study cycles, depending on the specific requirements of each group, may be classified as follows:

1. Standards of first cycle study programs;

2. Standards of second cycle study programs;

3. Standards of third cycle study programs.

The denominations of the standards of the first and second cycle study programs are the same, but they contain different criteria depending on the level of knowledge and diploma they provide.

These standards may be classified as follows:

1. Standard of the study program provided by the institution;

2. Standard of the organisation, orientation, and administration of the study program by the institution; 
3. Standard of the academic staff of the institution;

4. Standard of the protection of students' rights by the institution;

5. Standard of the provision of services and availability of libraries and other information resources provided to the students by the institution;

6. Standard of financial resources and financial assessment by the institution;

7. Standard of the guarantee of cooperation relations at a national and international level by the institution;

8. Standard of quality assurance by the institution.

$\mathrm{PhD}$ study programs are referred at these standards:

1. Third cycle study programs (Doctorate);

2. Scientific research;

3. Orientation and administration of the doctorate.

The arrangement of the requirements of each standard is exaggerated because their list is very long and there are often repetitions from an order to the other. For this case also, it is not clarified whether the 'Criteria' are mandatory or serve as an example on how the standards can be achieved (Timms, 2011).

From a positive perspective, regardless of the deficiencies in content, their impact is expected to be positive. The National Strategy for Higher Education states: "National Standards shall be used by the Public Agency for the Accreditation of Higher Education (PAAHE) and for the evaluation and accreditation of HEI and their programs".

Thus, issues such as integration of scientific research as a requirement of each program is expected to affect positively the improvement of the university education quality in all cycles, mainly Master and $\mathrm{PhD}$ studies.

Similarly, the standards see the quality of study programs in the light of a concrete and real study of the labour market, which will make them qualitative and competitive at a national and international level.

The development of the academic staff of HEI will undoubtedly have a considerable influence on the improvement of education quality that will better meet the growing demands of students.

From a critical perspective, again basing it on the situation of the higher education in Albania, we may say that because of the current advisory nature they have, their application will be difficult.

The opinion of the interviewees is that: the credibility of the study programs, in relation to what they offer, leaves much to be desired. The supervision that PAAHE exerts on study programs to date, preliminary evaluation and accreditation is formal. The documentation submitted by HEI, especially private ones, does not meet the criteria of these standards. Even though their documentation may be satisfactory on paper, however in reality it leaves much to be desired.

The quality of $\mathrm{PhD}$ programs also represents a serious issue. The National Strategy for Higher Education identifies that: "The relatively short experience with these programs and the observation that the standards of Albanian PhD do not always meet the international standards, make the extension of the quality assurance mechanisms in the third cycle crucial".

State standards on doctorate studies must be of an imperative nature. One year ago, such studies were exclusive to public universities, but 2011 brought liberalisation in regards to academic supply in the third study cycle, giving such a right also to private universities. Currently, only one private university is licensed to provide doctorate programs. (Minister of Education Order No. 503, dated 7 October 2011 "On the start of third cycle study programs, $\mathrm{PhD}$ studies in economic, social and legal sciences by the European University of Tirana") 
PROBLEMS

OF EDUCATION

IN THE $21^{\text {st }}$ CENTURY

Volume 42, 2012

In this regard, an international expertise would be very necessary both for the HEI and the PAAHE.

Thus, PAAHE as a new and inexperienced mechanism will indispensably need also foreign experts in their expert groups. These foreign experts must be experienced and professional so as to participate in the evaluation and accreditation of $\mathrm{PhD}$ programs.

\section{Quality Assurance in Higher Education Institutions}

Quality assurance for HEI is based on the existence of standards which serve as reference or as a system of criteria when it comes to external evaluation (quality assurance), or as a guideline on the internal organisation (quality management).

The first mechanism is the internal quality assurance by HEI themselves. Art. 59 of The Law on Higher Education states: "An internal quality control unit shall be established and operate with HEI".

On the other hand, the standards of study programs (orders 134, 135, and 136) include the existence of this mechanism. In accordance with them, this mechanism must become part of the organisational structure of the institution that must manage its first institutional accreditation and then, it must play a relevant role in the quality assurance of study programs.

The establishment and functioning of this mechanism, which is considered as a standard, is aimed at making HEI aware that its existence is indispensable and it must be rendered functional in order for it to become part of the internal culture of the institution.

For the purpose of assuring the application of this standard, in accordance with the abovementioned legal documents:

- The institution must draft a clear policy and follow a periodic evaluation of the efficiency of actions undertaken for the assurance of quality and standards of the study programs it provides;

- The institution must use formal mechanisms for the periodical examination, approval, and supervision of the study program it provides;

- The institution must aim at the increase of awareness of its staff and students who attend study programs over the importance of quality and quality assurance;

- The institution must draft and apply a strategy on the continuous improvement of quality and must make it public.

Only a real fulfilment of these functions by the internal quality control mechanism will make it possible for HEI to provide programs similar to the European Higher Education Area standards.

Based on the reality of HEI, the question posed to the interviewees was: 'How functional is the internal quality control mechanism?' The answer was: 'negative - not at all.'

To date, this mechanism has been addressed only at an ad-hoc level. As a mechanism, in the majority of cases, it only operates when institutions were facing the institutional and study programs accreditation process.

Regardless of the importance it presents for the quality of study programs, both public and private HEI have a low expectation for it. The study program quality concept is seen in a very tight perspective in the current Albanian higher education sector. It is related only to the curricula of a module/subject and the lecturer teaching it.

Even though the law on higher education and the relevant subordinate legal acts identify the necessity for the establishment and operation of this mechanism, in the Albanian education reality, it exists de jure in statutes and regulations of HEI but it does not operate de facto.

The second mechanism for the higher education quality assurance in Albania has to be the Public Agency for the Accreditation of Higher Education (PAAHE), which must apply the 
external quality assessment (Art. 60). I say "has to be" because currently it only manages the institutional and study programs assessments. It is not a decision-making body and it includes the Accreditation Council (AC) as a permanent mechanism which prepares the recommendatory decision regarding evaluation and institutional accreditation as well as accreditation of study programs.

Thereafter, the Minister of Education and Science has the exclusive competence to take the final decision whether to grant accreditation or not for the institution and study programs.

According to the current higher education legislation in Albania, the legal status of PAAHE is minimised by the dominant position held by the AC, which operates within it. Thus, there is a clash between the provisions of the higher education law, which specifies AC as a body which operates within the agency and the Decision of the Council of Ministers No. 424, dated 2 June 2010 "On the adoption of the regulation on the accreditation system, organisation, and activity of external quality assurance institutions", as amended and which specifies the Agency (PAAHE) and the Council (AC) as two independent mechanisms.

In my opinion and the opinion of the interviewees, currently PAAHE has a limited legal status. As abovementioned, the determinant position of the AC with PAAHE minimises its functions while at the same time deforms the role of the AC within PAAHE, which must ensure the observance of the evaluation and accreditation procedures and not specify them. It must operate as a "Board of trustworthy" in relation to PAAHE and to ratify its decisions (Timms, 2011).

On the other hand, the procedure followed regarding the external quality assessment, openly violates the independence relations of PAAHE. It does not have an autonomous accountability over its actions, and its considerations and recommendations are driven by the policies of the Ministry of Education, because it lacks of a mission statement and its independence does not exist.

\section{Approximation of the Albania Quality Standards to European Ones}

The sanctioning of a legal framework for the higher education quality state standards represents a very good step for the higher education reformation process.

The National Strategy for Higher Education states: "The needs of the country's future call for the three cycles of academic supply to meet the requirements of European Standards and the guidelines for the Quality Assurance in the European Higher Education Area".

The question which arises is: To what extent are the higher education state quality standards close to the Standards and Guidelines for Quality Assurance in the European Higher Education Area (Standards and Guidelines for Quality Assurance in the European Higher Education Area, 2009).

As also described above, state standards are classified in two major groups: institutional standards and study program state standards. Such division creates the impression that they were created for different purposes and are not in service to one another. The experience of different countries has covered them in a single document which enables the possibility for a consolidated and qualitative evaluation and accreditation of study programs and of the institution (Timms, 2011; Author's example - Handbook of Standards for Quality Management in French Higher Education Institutions).

Some of the standards, even though they are important ones, are not of academic nature and have little approach to the Standards and Guidelines for Quality Assurance in the European Higher Education Area. The standards' addressing issues such as controls in the size of windows and height of ceilings is far from being academic.

The standards are not accompanied by a manual, as envisaged in the Standards and Guidelines for Quality Assurance in the European Higher Education Area, in which each 
PROBLEMS

OF EDUCATION

IN THE $21^{\text {st }}$ CENTURY

Volume 42, 2012

standard is accompanied by a manual that provides necessary information on best practices and in several cases explains more clearly the reasoning and relevance of the standard.

Because they are presented as recommendations, there is no distinction among the standards to show which of them are fundamental and which of them are desirable to be achieved.

From this perspective, for the purpose of guaranteeing that higher education quality national standards have a similarity to European standards, it is necessary that they are reorganised and simplified. The purpose is to make them operational and applicable.

These standards should also focus on the role and position of the quality assessment mechanism. The procedures for the external quality assurance must take into account the effectiveness of the internal quality assurance processes, meaning each HEI should have the adequate policies and procedures for the internal quality assurance in regards to: periodic monitoring and evaluation of the programs and diplomas, evaluation of students, education staff quality assurance, education resources and support to students as well as information systems and public information.

State standards must ensure a similarity to the European ones in regards to the position of PAAHE, which must be restructured. The agency must go in line with European standards for external quality assurance agencies, while clearly specifying: Official status, Activities, Resources, Mission statement, Independence, Accountability procedures, External quality assurance criteria and processes used by the agency. Only by ensuring such status it may be able to play its role in the decision-making process for the external quality assurance. The process must be applied on clear "criteria," published and interpreted in a consequent manner and applied periodically.

An independent position, a specified mission and a transparent decision-making may provide for PAAHE its eventual membership in the European Association for Quality Assurance in Higher Education (ENQA).

\section{Conclusions}

The legal framework of quality state standards represents a positive step to ensure the quality of higher education in Albania. Such a framework makes HEI face the challenge of meeting quality state standards which, even though are not mandatory, are necessary for those HEI that want to create a clear physiognomy and become distinct in the higher education market.

The legal framework needs to be reviewed in order for it to have an adequate similarity to the Standards and Guidelines for Quality Assurance in the European Higher Education Area.

It would be better for the state standards addressed in the four subordinate legal acts to be joined in a single act so to avoid repetitions, be of an academic nature to ensure an evaluation and accreditation procedure which is discrete and independent both regarding the institution as well as the study programs.

The standards must be classified and a distinction must be made on which are fundamental and which are desirable to be achieved. The need for such a division is the result of the situation of the higher education in Albania which is characterized by fictiveness and a low public confidence.

State standards must be accompanied by manuals in order to ensure the provision of the necessary information on the best practices and in some cases to explain more clearly the reasoning and relevance of the standard.

The quality control mechanisms have to really operate. The internal quality assurance must be institutionalised as an indispensable and real mechanism of HEI.

In order to achieve membership in ENQA, PAAHE must show it is able to achieve standards in a "fundamental" manner, based on its official status, activity's rules of procedure, 
effectiveness of sources, clear purposes and objectives, independence of decision-making,

procedures for external quality assurance and accountability.

\section{References}

Decision of the Council of Ministers No. 1509 dated 30 July 2008 "On the adoption of Higher Education National Strategy, 2008-2013", Official Gazette of the Republic of Albania, no. 180/2008.

Decision of the Council of Ministers No. 424, dated 2 June 2010 "On the adoption of the regulation on the accreditation system, organisation, and activity of external quality assurance institutions," as amended, Official Gazette of the Republic of Albania, no.85/2010 \& Official Gazette of the Republic of Albania, no.81/2011.

Handbook of Standards for Quality Management in French Higher Education Institutions, URL: https:// www.cne-evaluation.fr/WCNE_pdf/LDRCNE_English.pdf

Law No. 9590, dated 27.July 2006 On the Ratification of "Stabilization and Association Agreement between Republic of Albania and the European Communities and their Member States", Official Gazette of the Republic of Albania, no. 87/2006.

Law No. 9741, dated 21 May 2007 "On Higher Education in the Republic of Albania," as amended, Official Gazette of the Republic of Albania, no. 68/2007 \& Official Gazette no.111/2010.

Linden T., Arnhold N., \& Vasiliev K. (2008), From Fragmentation to Cooperation: Tertiary Education, Research and Development in South Eastern Europe, 27. URL: http://web.worldbank.org/ / ALBANIA.

Minister of Education and Science Order No. 126, dated 17 March 2011, "On the adoption of quality state standards for the assessment and institutional accreditation of higher education institutions", URL: http://www.mash.gov.al

Minister of Education and Science Order No. 134, dated 21 March 2011 "On the adoption of quality state standards for the assessment and accreditation of higher education institutions' first cycle study programs", URL: http://www.mash.gov.al

Minister of Education and Science Order No. 135, dated 21 February 2011 "On the adoption of quality state standards for the assessment and accreditation of higher education institutions' second cycle study programs", URL: http://www.mash.gov.al

Minister of Education and Science Order No. 136, dated 21 February 2011 "On the adoption of quality state standards for the assessment and accreditation of higher education institutions' third cycle study programs", URL: http://www.mash.gov.al

Minister of Education Order No. 503, dated 7 October 2011 "On the start of third cycle study programs, $\mathrm{PhD}$ studies in economic, social, and legal sciences by the European University of Tirana", URL: http://www.mash.gov.al

Public Agency for the Accreditation of Higher Education (PAAHE), Annual Report (2011), URL: http:// www.apaal.gov.al.

Standards and Guidelines for Quality Assurance in the European Higher Education Area, (2009), $3^{\text {rd }}$ edition Helsinki

Timms, D. (2011). Support to PAAHE to ensure it matches up to international standards development. Review Report.

Advised by Nikoleta Mita, University of Tirana, Tirana, Albania

Received: January 12, 2012

Accepted: March 24, 2012

Juliana Latifi

Doctor, Lecturer in Education Law, Justicia University, Faculty of Law, Rr. Sami

Frashëri, P 24/1,Tirana, Albania.

E-mail: julilatifi@yahoo.com 